\title{
UPGRADING THE OLD VERNACULAR BUILDING TO CONTEMPORARY NORMS: MULTIPLE CRITERIA APPROACH
}

\author{
Eglè ŠIOŽINYTĖ, Jurgita ANTUCHEVIČIENĖ, Vladislavas KUTUT \\ Department of Construction Technology and Management, Vilnius Gediminas Technical University, \\ Sauletekio al. 11, 10223 Vilnius, Lithuania
}

Received 30 Oct 2013; accepted 28 Feb 2014

\begin{abstract}
Sustainable development is emphasized in the process of construction or modernization of buildings at present. Old vernacular architecture does not satisfy contemporary building norms such as daylighting and/or thermal performance parameters. These parameters are important for sustainability due to their relation with energy savings. It is obvious that seeking to improve these parameters, old buildings should be upgraded. The main problem is how to reach contemporary building norms without a negative impact to architectural heritage in a process of modernisation. The aim of the research is to find the best compromise solution for effective vernacular architecture's change. The Authors suggest using multiple criteria approach that enables to evaluate possible alternative solutions in several controversial aspects and to find rational building's modernisation type. Also, suitability of combination of usual MCDM (Multiple Criteria Decision Making) methods with grey systems theory due to possibility of processing of large quantity of uncertain information is highlighted in the research. TOPSIS Grey (Technique for Order Preference by Similarity to Ideal Solution with grey numbers) and AHP (Analytic Hierarchy Process) methods are applied for the presented case study of upgrading the old vernacular building. Taking into account multiple quantitative and qualitative criteria and experts' opinion, the rational vernacular building's modernisation variant is chosen. Based on the comprehensive analysis, research conclusions and recommendations are formulated.
\end{abstract}

Keywords: vernacular building, vernacular architecture, upgrading, modernisation, sustainable development, MCDM, TOPSIS Grey, AHP.

Reference to this paper should be made as follows: Šiožinytė, E.; Antuchevičienė, J.; Kutut, V. 2014. Upgrading the old vernacular building to contemporary norms: multiple criteria approach, Journal of Civil Engineering and Management 20(2): 291-298. http://dx.doi.org/10.3846/13923730.2014.904814

\section{Introduction}

Sustainable building development includes such principles as creating healthy environment, using green materials and technologies, energy and other natural resource savings, recycling, reusing, etc. Sustainable building development is topical today and is taken into consideration by various researchers. They analyse problems related with energy efficiency and building's envelope (Ourghi et al. 2007; Parasonis et al. 2012; Yüksek, Esin 2013; Kazanasmaz et al. 2014); building materials (Binici et al. 2014; Pajchrowski et al. 2014); analyse importance of buildings' modernisation (Staniūnas et al. 2013; Volvačiovas et al. 2013a); create strategies related with building upgrading (Volvačiovas et al. 2013b; Itani et al. 2013).

There are lots of buildings that require a new approach to their complexion. Old vernacular buildings also require a new approach. These buildings often do not satisfy some important parameters of sustainable development, e.g. daylighting and/or thermal performance (energy saving aspect). Buildings use a lot of energy for their lighting and/or heating. Modernization of these buildings can help to reduce energy consumption. But in this case we face the problem that commonly used modernization solutions are hardly compatible with preservation of traditional vernacular buildings' appearance.

Some parts of the building, such as walls and windows, are the most affected and can make a huge influence on building's appearance while seeking to satisfy contemporary building norms. Thermal insulation could be added to the walls; windows could be resized, the quantity of windows or their style could be changed. Other parts of the building, such as roof, floor, doors, base, etc. can be changed/modernised/renewed quite easily and do not make significant influence from the visual aspect.

The current research is the continuous work about balance between contemporary norms and tradition continuity. Earlier research described the possible indoor daylighting problem and presented possible ways of improving indoor daylighting for vernacular architecture when trying to save tradition and satisfy minimal daylighting norms determined in the building regulations. The problem was analysed using Multiple Criteria Decision Making (MCDM) methods such as AHP, COPRAS, TOPSIS, WASPAS (Šiožinytè, Antuchevičienè 2013). 


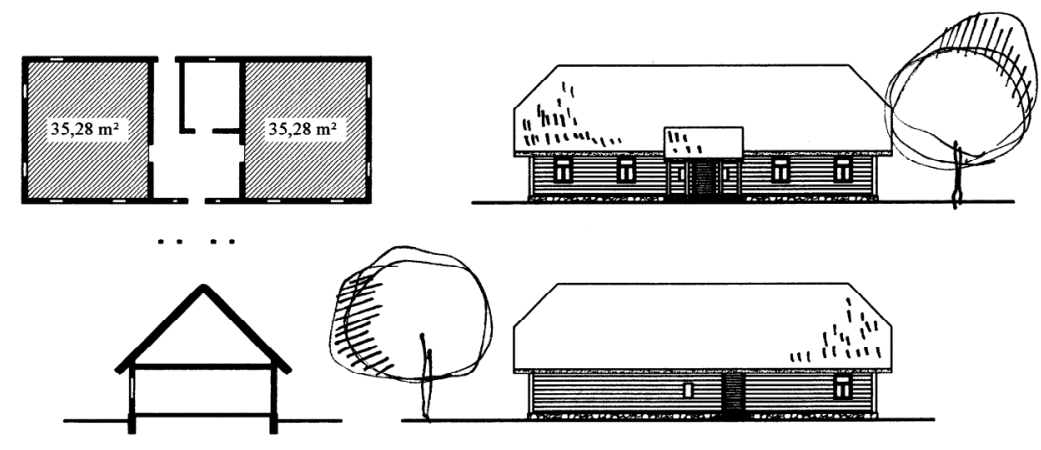

a)

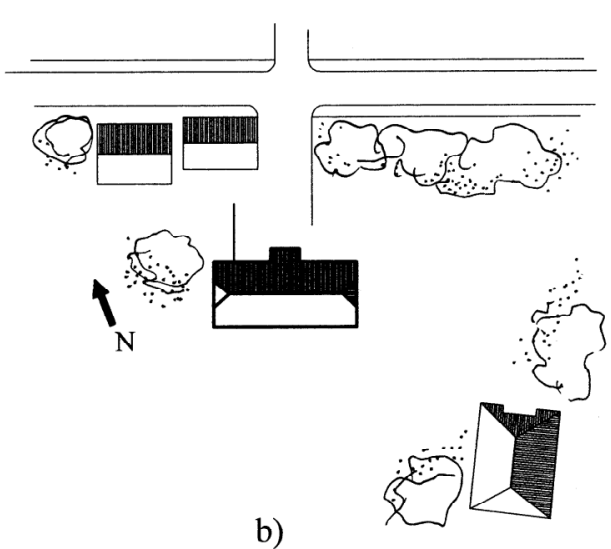

b)

Fig. 1. Vernacular building from Aukštaitija region, Lithuania (Šešelgis et al. 1965): a) architecture; b) situation

The aim and the novelty of the current research is to evaluate the whole vernacular building (not one specific part, e.g. windows, like it was made earlier) using multiple criteria approach and grey system theory. Some researchers applied MCDM methods for rural buildings' development through re-using, preservation, conservation, regeneration, etc., aspects. They are seeking for ranking the rational solutions, such as, rural buildings' regeneration alternatives (Zavadskas, Antucheviciene 2007); evaluating rational solutions for rural ITC centers (telecenters) (Hashemkhani Zolfani et al. 2012); allowing the reduction of deterioration models of rural buildings subjectively (Cano et al. 2013); identifying the best re-use variant of an abandoned rural village (Russo et al. 2013). Overall, MCDM methods are suitable for various kinds of complex construction economics problems (Kapliński, Tupenaite 2011; Zavadskas, Turskis 2011).

Other researchers analyze vernacular architecture in different aspects separately. Topical themes are related with building technologies and indoor environment (Hoof, Dijken 2008; Foruzanmehr, Vellinga 2011), external appearance (Porto, Cascone 2013), ecology, energy efficiency (Keizikas et al. 2012), etc.

For this case study the research object is analysed from the aspect of sustainable development and tradition continuity and using multiple quantitative and qualitative criteria. Nine possible variants for vernacular building modernization are proposed and ten criteria for their evaluation are suggested. Each criterion is weighted using Analytic Hierarchy Process. Criteria are expressed in intervals using grey numbers. Variants of building modernisation are ranked and the most suitable is selected using TOPSIS Grey method.

\section{Searching the most suitable way of modernisation for vernacular building}

\subsection{Object}

The research is exemplified by the case study. Object of the case study is the vernacular dwelling from Aukštaitija region, Lithuania (Fig. 1). Wooden building was constructed at the end of XIX century. The architecture is typical for the region's rural architecture: sloped straw roof, $20 \mathrm{~cm}$ wide $\log$ walls, $0.7 \times 1.0 \mathrm{~m}$ windows, stone foundation. Building is situated to the North-East direction at the site.

\subsection{Building modernisation alternatives and criteria for assessment of solutions}

Chosen vernacular building does not satisfy contemporary daylighting and thermal performance norms. The aim is to find the rational architectural solution that combines contemporary norms and tradition continuity.

Four components, such as architectural heritage, requirements (norms), energy and comfort are proposed for searching rational solutions for old vernacular architecture. Each component can be described by various criteria. According to Figure 2 the criteria system have been formulated for the case study.

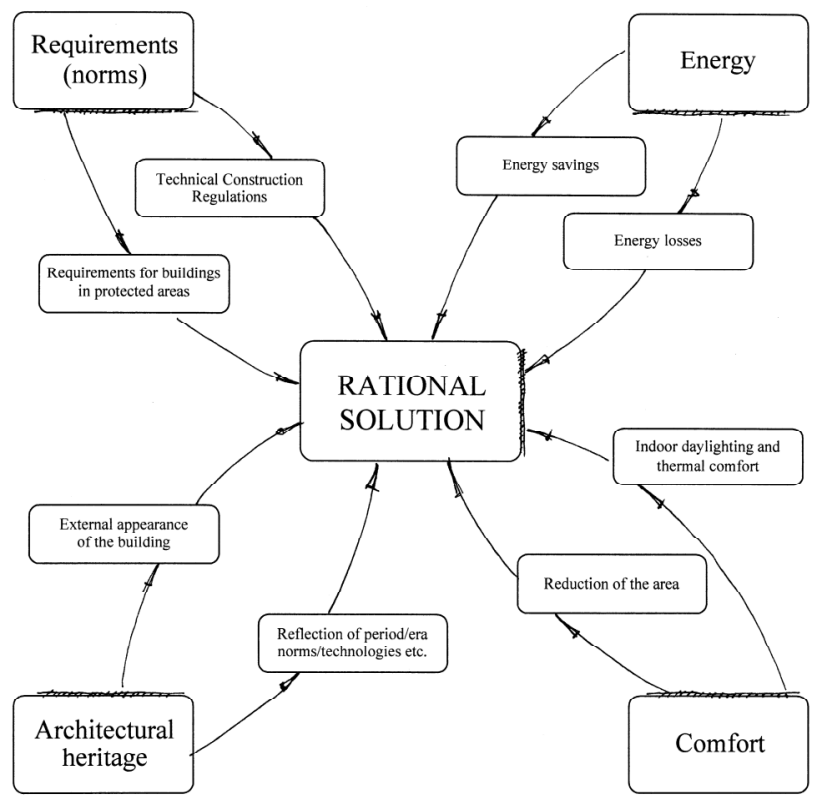

Fig. 2. Consistency between four components while seeking for sustainable development of old vernacular architecture

Criteria for ranking the variants of building renovation are presented in Table 1. 


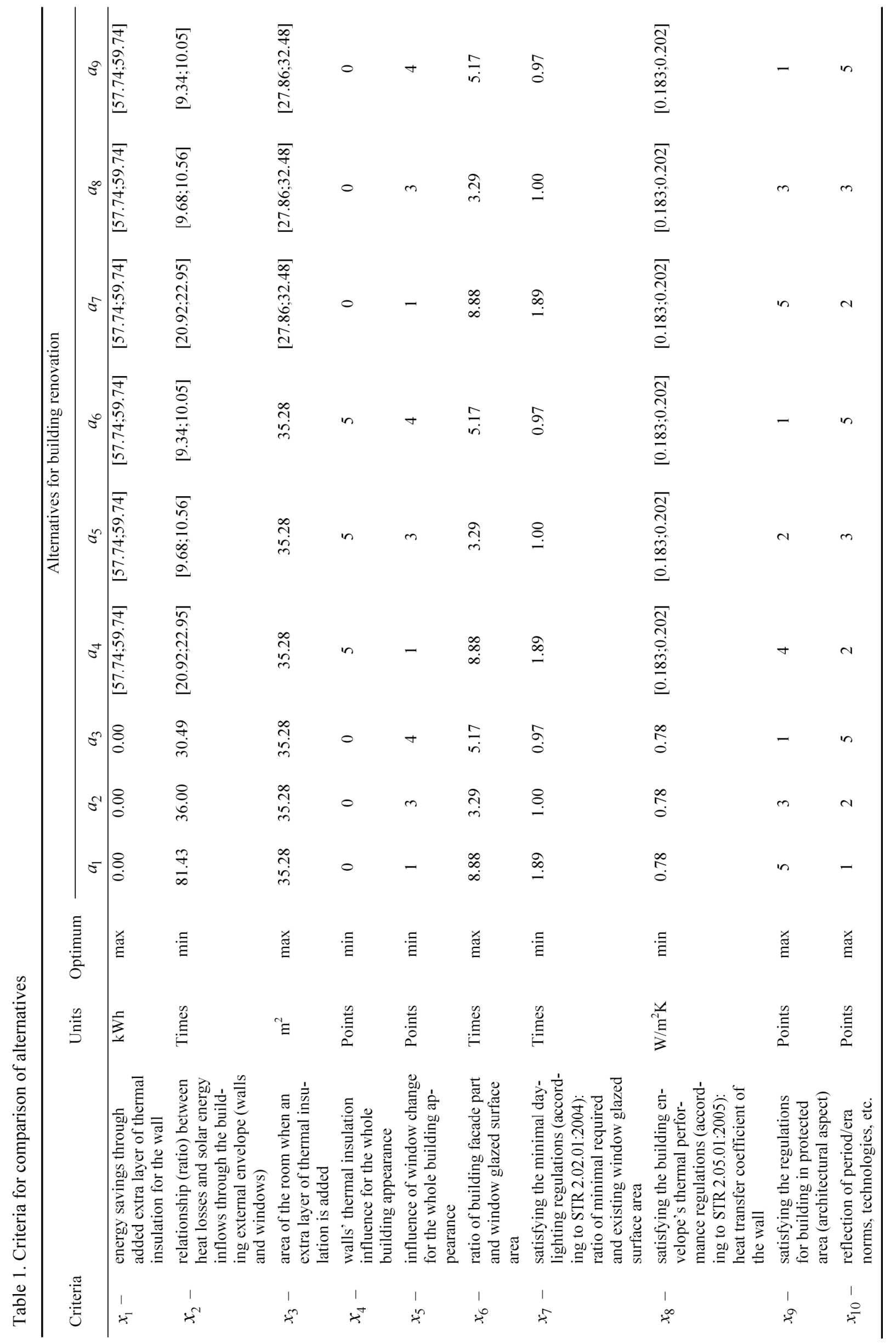


Criteria are evaluated using quantitative $\left(x_{1}, x_{2}, x_{3}, x_{6}, x_{7}, x_{8}\right)$ and qualitative $\left(x_{4}, x_{5}, x_{9}, x_{10}\right)$ measures. Quantitative measures are evaluated according to Technical Construction Regulations for the buildings (STR 2.02.01:2004; STR 2.05.01:2005). Qualitative measures are evaluated using the scale based on five-level Likert item scale ( 1 - very weak; 2 - weak; 3 - medium; 4 - strong; 5 - very strong).

Alternatives are formed considering the mentioned above energy parameters through the energy saving aspect. Windows and walls are the parts of the building that have influence on the external building's appearance when trying to satisfy daylighting and thermal performance norms as described in building regulations. The original $0.20 \mathrm{~m}$ wooden wall has a quite good thermal resistance and it is possible that together with solar energy inflows through the building external envelope can reach required thermal performance. Other parts of the building (floor, roof, doors, base, etc.) are not taken into consideration due to their small influence to building's appearance when upgrading the building.

Figure 3 demonstrates wall types for this case study: a) original wall (without thermal insulation); b) thermal insulation added outside the wall; c) thermal insulation added inside the room.

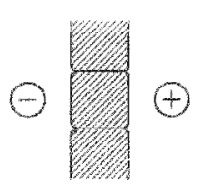

)

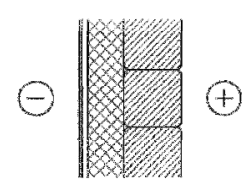

b)

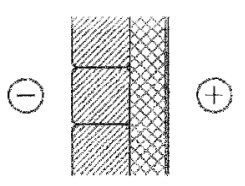

c)
Fig. 3. Wall types: a) without thermal insulation; b) thermal insulation outside the wall; c) thermal insulation inside the room

Window variants for solving daylighting problems are described in detail by Šiožinytè and Antuchevičienè (2013). Also, some of criteria are taken from a previous research.

Possible alternatives for building renovation are composed of different wall and window modernization solutions. Analysed alternatives for building renovation are as follows: $a_{1}$ wall without thermal insulation and increased size of the window, while maintaining the typical traditional proportions; $a_{2}-$ wall without thermal insulation and increased quantity of the windows; $a_{3}-$ wall without thermal insulation and used the new glass structures for building facades (modern window solution); $a_{4}$-thermal insulation added outside the wall and the window size increased, while maintaining the typical traditional proportions; $a_{5}-$ thermal insulation added outside the wall and increased quantity of the windows; $a_{6}$ - thermal insulation added outside the wall and used the new glass structures for building facades (modern window solution); $a_{7}$ - thermal insulation added inside the room and the window size increased, while maintaining the typical traditional proportions; $a_{8}-$ thermal insulation added inside the room and increased quantity of the windows; $a_{9}$-thermal insulation added inside the room and used the new glass structures for building facades (modern window solution).

\section{Methodology for ranking of alternatives}

\subsection{AHP method}

AHP method is based on pairwise comparisons of criteria. This method was introduced by Saaty (1980) for measuring the intensity of importance of criteria according to the experts' opinion.

For this case study the expert team from 6 civil engineers and 10 architectural engineers (16 experts at all) was created. Experts' judgment on importance of criteria was expressed using the scale from 1 to 5 in the current case. The decision about the consistency of performed comparisons was made on the basis of the Consistency Ratio (CR). Geometric mean technique was used to aggregate judgments of all experts.

\subsection{TOPSIS Grey method}

TOPSIS method with grey numbers was introduced by Lin et al. (2008). The method is used for problem solving with uncertain information and presented with reference to Zavadskas et al. (2010), Hashemkhani Zolfani et al. (2012), also Hashemkhani Zolfani and Antucheviciene (2012).

TOPSIS Grey method includes the following steps:

1. Describing alternatives and selecting important criteria.

2. Constructing the decision-making matrix $\otimes X$ :

$$
\otimes X=\left[\begin{array}{rrrr}
\otimes x_{11} & \otimes x_{12} & \cdots & \otimes x_{1 m} \\
\otimes x_{21} & \otimes x_{22} & \cdots & \otimes x_{2 m} \\
& :: \vdots & & \\
\otimes x_{21} & \otimes x_{n 2} & \cdots & \otimes x_{n m}
\end{array}\right] ; i=\overline{1, n} ; j=\overline{1, m}
$$

where: $\otimes x_{i j}$ enotes the grey evaluations of the $i^{\text {th }}$ alternative with respect to the $j^{\text {th }}$ attribute $\left[\begin{array}{llll}\otimes x_{i 1} & \otimes x_{i 2} & \cdots & \otimes x_{i m}\end{array}\right]$; the grey number evaluation series of the $i^{\text {th }}$ alternative.

3. Constructing the normalised decision-making matrix. Normalised values of maximizing and minimizing attributes are calculated as follows:

$\otimes \bar{x}_{i j, b}=\frac{\otimes x_{i j}}{\max _{i}\left(b_{i j}\right)}=\left(\frac{w_{i j}}{\max _{i}\left(b_{i j}\right)} ; \frac{b_{i j}}{\max _{i}\left(b_{i j}\right)}\right)$

and

$\otimes \bar{x}_{i j, w}=\frac{\otimes x_{i j}}{\max _{i}\left(b_{i j}\right)}=\left(1-\frac{b_{i j}}{\max _{i}\left(b_{i j}\right)} ; 1-\frac{w_{i j}}{\max _{i}\left(b_{i j}\right)}\right)$.

4. Weighting the normalised decision-making matrix.

5. Determining ideal and negative-ideal solutions. The positive ideal alternative $A^{+}$, and the negative ideal alternative $A^{-}$can be defined as follows: 


$$
\begin{aligned}
A^{+}= & \left\{\left(\max _{i} \bar{b}_{i j} \mid j \in J\right),\left(\min _{i} \bar{w}_{i j} \mid j \in J^{\prime}\right), i \in n\right\}= \\
& \left\{\bar{x}_{1}^{+}, \bar{x}_{2}^{+}, \ldots, \bar{x}_{m}^{+}\right\}
\end{aligned}
$$

and

$$
\begin{aligned}
A^{-}= & \left\{\left(\min _{i} \bar{w}_{i j} \mid j \in J\right),\left(\max _{i} \bar{b}_{i j} \mid j \in J^{\prime}\right), i \in n\right\}= \\
& \left\{\bar{x}_{1}^{-}, \bar{x}_{2}^{-}, \ldots, \bar{x}_{m}^{-}\right\} .
\end{aligned}
$$

6. Calculating the separation measure from the positive and negative ideal alternatives:

$$
L_{i}^{+}=\sqrt{\frac{1}{2} \sum_{j=1}^{m} q_{i}\left[\left|\bar{x}_{j}^{+}-\bar{b}_{i j}\right|^{2}+\left|\bar{x}_{j}^{+}-\bar{b}_{i j}\right|^{2}\right]}
$$

and

$$
L_{i}^{-}=\sqrt{\frac{1}{2} \sum_{j=1}^{m} q_{i}\left[\left|\bar{x}_{j}^{-}-\bar{b}_{i j}\right|^{2}+\left|\bar{x}_{j}^{-}-\bar{b}_{i j}\right|^{2}\right]} .
$$

7. Calculating the relative closeness $K_{i}^{+}$to the positive ideal alternative for the group:

$$
K_{i}^{+}=\frac{L_{i}^{-}}{L_{i}^{+}+L_{i}^{-}}, 0 \leq K_{i}^{+} \leq 1 .
$$

8. Ranking the preference order.

TOPSIS Grey method was chosen by its suitability for problem solving with uncertain information, expressed in intervals. For this case study information related with thermal insulation materials is considered to be uncertain information. It is not very important to choose the exact thermal insulation material at the first stage of the research. At the first stage the type of materials can be chosen, i.e. from raw materials (straws, sheep wool, etc.) to various kinds of mineral wools. The particular thermal insulation material could be chosen in the next step of the research, after selecting the alternative of buil- ding modernisation/renovation and the type of thermal insulation material simultaneously.

\section{Calculation results: weighting criteria and evaluating the alternatives}

Weights of the criteria $w_{i}$ are determined by applying AHP method (Table 2).

The Consistency Ratio coefficient is calculated as follows (for description of methodology see Saaty 1980; Wang et al. 2013; Šiožinytė, Antuchevičienè 2013): 1) $\lambda_{\max }=10.1220$; 2) $C I=0.0135$; 3) $R C I=1.4900$; 4) $C R=0.0091$.

The Consistency Ratio does not exceed the condition $C R<0.1$. It means that the judgements are consistent and the weights of criteria can be used for the further alternative ranking.

The alternatives ranking when applying TOPSIS Grey method is presented in Tables 3-6.

According to the results (Table 6) the alternatives are ranked as follows:

$$
a_{7} \succ a_{8} \succ a_{9} \succ a_{4} \succ a_{5} \succ a_{6} \succ a_{1} \succ a_{2} \succ a_{3} .
$$

In the case study the best alternative is the alternative $a_{7}$ where thermal insulation is added to the wall inside the room and the window size increased, while maintaining the typical traditional proportions when seeking to improve daylighting and thermal performance parameters and to meet current building regulations/norms.

By the ranking of weights of the criteria it is seen that thermal performance properties are more important

\begin{tabular}{|c|c|c|c|c|c|c|c|c|c|c|c|}
\hline & \multicolumn{10}{|c|}{ Criteria } \\
\hline & & $x_{1}$ & $x_{2}$ & $x_{3}$ & $x_{4}$ & $x_{5}$ & $x_{6}$ & $x_{7}$ & $x_{8}$ & $x_{9}$ & $x_{10}$ \\
\hline \multirow{11}{*}{ : } & $x_{1}$ & 1.0000 & 1.5976 & 2.1335 & 0.8596 & 1.0443 & 1.5935 & 1.4927 & 0.8839 & 0.6148 & \\
\hline & $x_{2}$ & 0.6260 & 1.0000 & 1.5474 & 0.9207 & 0.9686 & 1.8998 & 1.3064 & 0.5926 & 0.6660 & 1.3643 \\
\hline & $x_{3}$ & 0.4687 & 0.6463 & 1.0000 & 0.5596 & 0.7019 & 1.0074 & 0.7414 & 0.3893 & 0.4641 & 1.2428 \\
\hline & $x_{4}$ & 1.1633 & 1.0861 & 1.7869 & 1.0000 & 1.3098 & 1.5576 & 1.1501 & 0.7048 & 0.7100 & 1.8476 \\
\hline & $x_{5}$ & 0.9576 & 1.0324 & 1.4247 & 0.7635 & 1.0000 & 1.3012 & 0.8138 & 0.6484 & 0.5324 & 1.5576 \\
\hline & $x_{6}$ & 0.7199 & 0.5264 & 0.9927 & 0.6420 & 0.7685 & 1.0000 & 0.6054 & 0.3973 & 0.6331 & 1.0754 \\
\hline & $x_{7}$ & 0.6699 & 0.7654 & 1.3488 & 0.8695 & 1.2287 & 1.6518 & 1.0000 & 0.7210 & 0.7641 & 1.2935 \\
\hline & $x_{8}$ & 1.1313 & 1.6874 & 2.5690 & 1.4189 & 1.5422 & 2.5168 & 1.3870 & 1.0000 & 1.1892 & 1.6507 \\
\hline & $x_{9}$ & 1.6265 & 1.5014 & 2.1548 & 1.4085 & 1.8783 & 1.5794 & 1.3087 & 0.8409 & 1.0000 & 1.6224 \\
\hline & $x_{10}$ & 0.6704 & 0.7330 & 0.8046 & 0.5413 & 0.6420 & 0.9299 & 0.7731 & 0.6058 & 0.6164 & 1.0000 \\
\hline & $w_{i}$ & 1158 & 0.0977 & 0.0647 & 0.1120 & 0.0913 & 0.0678 & 0.0946 & 0.1475 & 0.1395 & 0.0692 \\
\hline
\end{tabular}
than daylighting properties for this case study's experts. When talking about the external appearance of the building, the results show that priority is taken to architecture with traditional appearance (traditional type of the window and traditional view of the wall), no matter that the building does not meet daylighting norms.

Table 2. Weights of the criteria $w_{\mathrm{j}}$ 
Table 3. Normalised decision-making matrix

\begin{tabular}{|c|c|c|c|c|c|c|c|c|c|c|c|c|}
\hline \multicolumn{3}{|c|}{ Criteria } & $\bar{x}_{1}$ & $\bar{x}_{2}$ & $\bar{x}_{3}$ & $\bar{x}_{4}$ & $\bar{x}_{5}$ & $\bar{x}_{6}$ & $\bar{x}_{7}$ & $\bar{x}_{8}$ & $\bar{x}_{9}$ & $\bar{x}_{10}$ \\
\hline \multirow{18}{*}{ 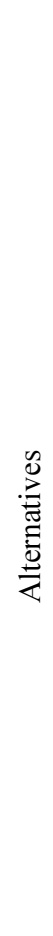 } & \multirow{2}{*}{$a_{1}$} & $\bar{w}$. & 0000 & 0.0000 & 1.0000 & 1.0000 & 0.7500 & 1.0000 & 0.0000 & 0.0000 & 1.0000 & 0.2000 \\
\hline & & $\bar{b}$. & 0000 & 0.0000 & 1.0000 & 1.0000 & 0.7500 & 1.0000 & 0.0000 & 0.0000 & 1.0000 & 0.2000 \\
\hline & \multirow{2}{*}{$a_{2}$} & $\bar{w}$ & 0.0000 & 0.5579 & 1.0000 & 1.0000 & 0.2500 & 0.3705 & 0.4709 & 0.0000 & 0.6000 & 0.4000 \\
\hline & & $\bar{b}$ & 0.0000 & 0.5579 & 1.0000 & 1.0000 & 0.2500 & 0.3705 & 0.4709 & 0.0000 & 0.6000 & 0.4000 \\
\hline & \multirow{2}{*}{$a_{3}$} & $\bar{w}$ & 0.0000 & 0.6256 & 1.0000 & 1.0000 & 0.0000 & 0.5822 & 0.4868 & 0.0000 & 0.2000 & 1.0000 \\
\hline & & $\bar{b}$ & 0.0000 & 0.6256 & 1.0000 & 1.0000 & 0.0000 & 0.5822 & 0.4868 & 0.0000 & 0.2000 & 1.0000 \\
\hline & \multirow{2}{*}{$a_{4}$} & $\bar{w}$ & 0.9163 & 0.7182 & 1.0000 & 0.0000 & 0.7500 & 1.0000 & 0.0000 & 0.7410 & 0.8000 & 0.4000 \\
\hline & & $\bar{b}$ & 1.0000 & 0.7431 & 1.0000 & 0.0000 & 0.7500 & 1.0000 & 0.0000 & 0.7654 & 0.8000 & 0.4000 \\
\hline & \multirow{2}{*}{$a_{5}$} & $\bar{w}$ & 0.9163 & 0.8703 & 1.0000 & 0.0000 & 0.2500 & 0.3705 & 0.4709 & 0.7410 & 0.4000 & 0.6000 \\
\hline & & $\bar{b}$ & 1.0000 & 0.8811 & 1.0000 & 0.0000 & 0.2500 & 0.3705 & 0.4709 & 0.7654 & 0.4000 & 0.6000 \\
\hline & \multirow[t]{2}{*}{$a_{6}$} & $\bar{w}$ & 0.9163 & 0.8766 & 1.0000 & 0.0000 & 0.0000 & 0.5822 & 0.4868 & 0.7410 & 0.2000 & 1.0000 \\
\hline & & $\bar{b}$ & 1.0000 & 0.8853 & 1.0000 & 0.0000 & 0.0000 & 0.5822 & 0.4868 & 0.7654 & 0.2000 & 1.0000 \\
\hline & \multirow[t]{2}{*}{$a_{7}$} & $\bar{w}$ & 0.9163 & 0.7182 & 0.7897 & 1.0000 & 0.7500 & 1.0000 & 0.0000 & 0.7410 & 1.0000 & 0.4000 \\
\hline & & $\bar{b}$ & 1.0000 & 0.7431 & 0.9206 & 1.0000 & 0.7500 & 1.0000 & 0.0000 & 0.7654 & 1.0000 & 0.4000 \\
\hline & \multirow[t]{2}{*}{$a_{8}$} & $\bar{w}$ & 0.9163 & 0.8703 & 0.7897 & 1.0000 & 0.2500 & 0.3705 & 0.4709 & 0.7410 & 0.6000 & 0.6000 \\
\hline & & $\bar{b}$ & 1.0000 & 0.8811 & 0.9206 & 1.0000 & 0.2500 & 0.3705 & 0.4709 & 0.7654 & 0.6000 & 0.6000 \\
\hline & \multirow[t]{2}{*}{$a_{9}$} & $\bar{w}$ & 0.9163 & 0.8766 & 0.7897 & 1.0000 & 0.0000 & 0.5822 & 0.4868 & 0.7410 & 0.2000 & 1.0000 \\
\hline & & $\bar{b}$ & 1.0000 & 0.8853 & 0.9206 & 1.0000 & 0.0000 & 0.5822 & 0.4868 & 0.7654 & 0.2000 & 1.0000 \\
\hline
\end{tabular}

Table 4. Normalised-weighted decision-making matrix

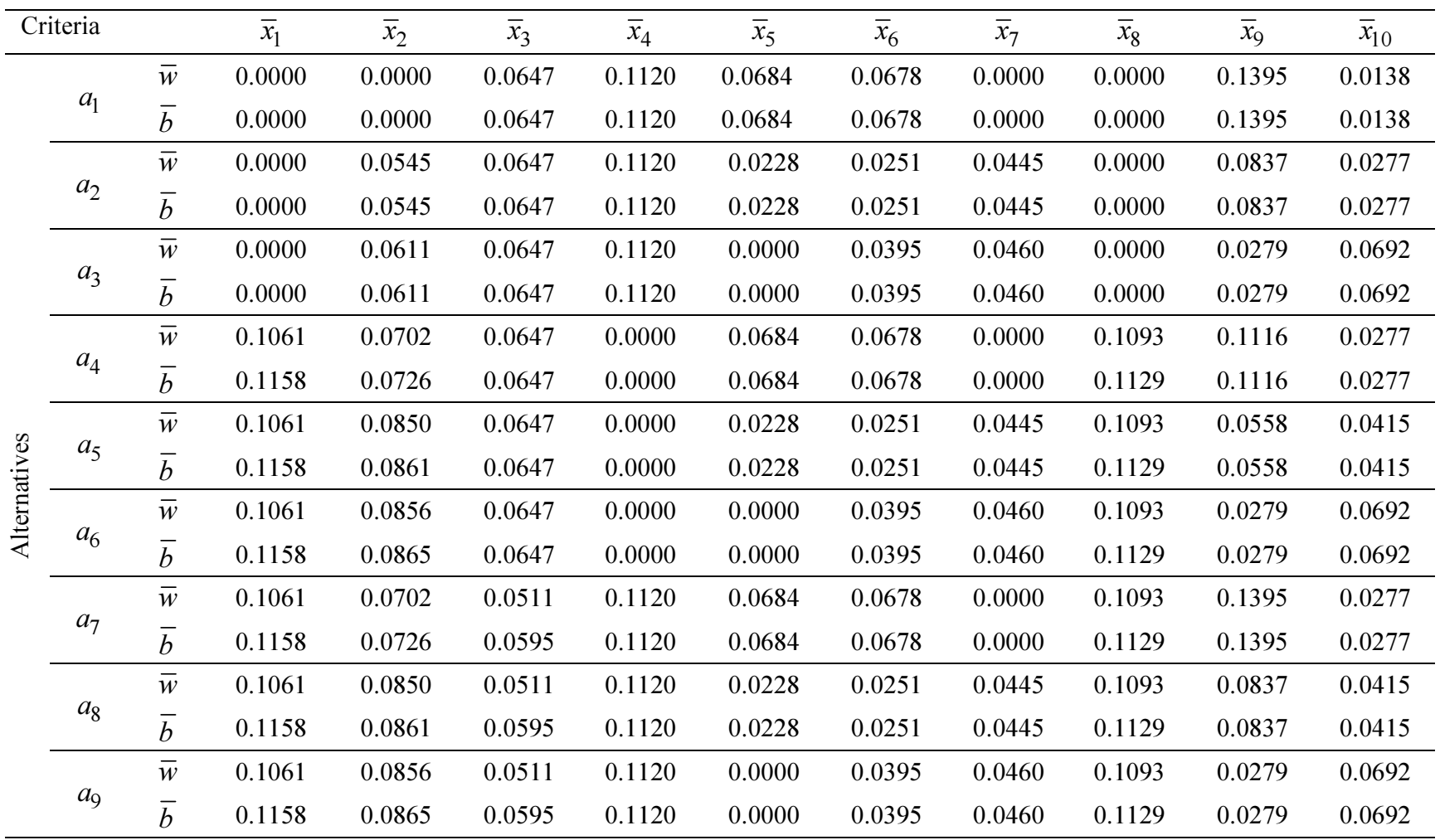


Table 5. Ideal and negative-ideal solutions

\begin{tabular}{ccccccccccc}
\hline Criteria & $\bar{x}_{1}$ & $\bar{x}_{2}$ & $\bar{x}_{3}$ & $\bar{x}_{4}$ & $\bar{x}_{5}$ & $\bar{x}_{6}$ & $\bar{x}_{7}$ & $\bar{x}_{8}$ & $\bar{x}_{9}$ & $\bar{x}_{10}$ \\
\hline$A^{w+}$ & 1061 & 0.0856 & 0.0647 & 0.1120 & 0.0684 & 0.0678 & 0.0460 & 0.1093 & 0.1395 & 0.0692 \\
$A^{b+}$ & 1158 & 0.0865 & 0.0647 & 0.1120 & 0.0684 & 0.0678 & 0.0460 & 0.1129 & 0.1395 & 0.0692 \\
$A^{w-}$ & 0000 & 0.0000 & 0.0511 & 0.0000 & 0.0000 & 0.0251 & 0.0000 & 0.0000 & 0.0279 & 0.0138 \\
$A^{b-}$ & 0000 & 0.0000 & 0.0595 & 0.0000 & 0.0000 & 0.0251 & 0.0000 & 0.0000 & 0.0279 & 0.0138 \\
\hline
\end{tabular}

Table 6. Results

\begin{tabular}{cccccccccc}
\hline Alternatives & $a_{1}$ & $a_{2}$ & $a_{3}$ & $a_{4}$ & $a_{5}$ & $a_{6}$ & $a_{7}$ & $a_{8}$ & $a_{9}$ \\
\hline$L_{i}^{+}$ & 1930 & 0.1855 & 0.2079 & 0.1318 & 0.1556 & 0.1746 & 0.0645 & 0.0888 & 0.1343 \\
$L_{i}^{-}$ & 1778 & 0.1464 & 0.1476 & 0.2088 & 0.1901 & 0.1939 & 0.2479 & 0.2256 & 0.2236 \\
$K_{i}$ & 4794 & 0.4410 & 0.4151 & 0.6130 & 0.5499 & 0.5262 & 0.7935 & 0.7176 & 0.6248 \\
\hline
\end{tabular}

Dividing experts into the groups by their professions, the results showed that civil engineers and architectural engineers evaluate alternatives quite similarly: the three best alternatives are $a_{7} \succ a_{8} \succ a_{9}$ (the same as the both groups evaluated together). The further alternatives are ranked differently and it is seen that architectural engineers give their priority to the architectural properties and civil engineers give their priority to the energy saving parameters. Also it can be noticed that both groups understand the importance of saving traditional building's appearance.

\section{Conclusions}

Current research was focused on sustainable old vernacular architecture's development and tradition continuity aspect. Multiple criteria approach was proposed for assessment of the whole building (not for one specific part of the building as in many other researches). Also, the findings of rational building's modernisation variant have been made.

It was proposed to apply grey number theory due to its possibility to use uncertain information, expressed in intervals. For this case study as uncertain information was considered information related with thermal insulation materials. TOPSIS Grey method was applied for current research. AHP method was applied to determine relative significances of the quantitative and qualitative criteria.

The presented case study of old vernacular building shows that the rational variant of building's modernisation is when the small interventions to the building's external appearance are made seeking to improve thermal performance and daylighting characteristics. For the current example, thermal insulation was added inside the room of the building and windows were increased, maintaining their typical traditional proportions.

Comparing the current and earlier case studies results, it was concluded that evaluation of one specific part of the building, e.g. windows, is not the same as the complete evaluation of the whole building. Modern window solution was the best variant when alternatives for solving the daylighting problem were ranked (Šiožinyte, Antuchevičienè 2013). In this case study according to experts'opinion the daylighting parameters are less important when the whole building is evaluated. In their opinion tradition is much important than current norms when analysing vernacular buildings' modernization. The established priority order of modernization alternatives confirmed this attitude.

It is noticed that judgements of the experts are close related with their intelligence: profession, logic, knowledge about vernacular architecture, etc. These judgements are quite subjective. For more objective assessment different methods could be applied.

It can be assumed that it is not enough to evaluate separate parts of a building, even using a number of criteria for analysis, when making important decisions, such as vernacular architecture's change. It is suggested to evaluate upgrading of the whole building simultaneously and using multiple criteria approach. Also, every evaluated building should always be considered individually due to its different parameters (situation in the area, architecture, construction, etc.).

\section{References}

Binici, H.; Eken, M.; Dolaz, M.; Aksogan, O.; Kara, M. 2014. An environmentally friendly thermal insulation materials from sunflower stalk, textile waist and stubble fibres, Construction and Building Materials 51: 24-33. http://dx.doi.org/10.1016/j.conbuildmat.2013.10.038

Cano, M.; Garzón, E.; Sánchez-Soto, P. J. 2013. Preservation and conservation of rural buildings as a subject of cultural tourism: a review concerning the application of new technologies and methodologies, Journal of Tourism \& Hospitality 2(2): 115.

http://dx.doi.org/10.4172/2167-0269.1000115

Foruzanmehr, A.; Vellinga, M. 2011.Vernacular architecture: questions of comfort and practicability, Building Research \& Information 39(3): 274-275.

http://dx.doi.org/10.1080/09613218.2011.562368

Hashemkhani Zolfani, S.; Sedaghat, M.; Zavadskas, E. K. 2012. Performance evaluating of rural ICT centers (telecenters), applying Fuzzy AHP, SAW-G and TOPSIS Grey, a case study in Iran, Technological and Economic Development of Economy 18(2): 364-387. http://dx.doi.org/10.3846/20294913.2012.685110

Hashemkhani Zolfani, S.; Antucheviciene, J. 2012. Team member selecting based on AHP and TOPSIS Grey, Inzinerine Ekonomika - Engineering Economics 23(4): 425-434. 
Hoof, J.; Dijken, F. 2008. The historical turf farms of Iceland: architecture, building technology and the indoor environment, Building and Environment 43(6): 1023-1030. http://dx.doi.org/10.1016/j.buildenv.2007.03.004

Itani, T.; Ghddar, N.; Ghali, K. 2013. Strategies for reducing energy consumption in existing office buildings, International Journal of Sustainable Energy 32(4): 259-275. http://dx.doi.org/10.1080/14786451.2011.622765

Kapliński, O.; Tupenaite, L. 2011. Review of the multiple criteria decision making methods, intelligent and biometric systems applied in modern construction economics, Transformations in Business \& Economics 10(1): 166-181.

Kazanasmaz, T.; Uygun, I. E.; Akkurt, G. G.; Turhan, C.; Ekmen, K. E. 2014. On the relation between architectural considerations and heating energy performance of Turkish residential buildings in Izmir, Energy and Buildings 72: 38-50. http://dx.doi.org/10.1016/j.enbuild.2013.12.036

Keizikas, A.; Andriušyte, A.; Šiožinytè, E. 2012. Research of some aspects of relation between ecology and energy efficiency in traditional architecture, Evolution of Science and Technology 4(1): 47-61 (in Lithuanian). http://dx.doi.org/10.3846/est2011.04

Lin, Y.-H.; Lee, P.-C.; Chang, T.-P.; Ting, H.-I. 2008. Multiattribute group decision making model under the condition of uncertain information, Automation in Construction 17(6): $792-797$. http://dx.doi.org/10.1016/j.autcon.2008.02.011

Ourghi, R.; AlAnzi, A.; Krarti, M. 2007. A simplified analysis method to predict the impact of shape on annual energy use for office buildings, Energy Conversion and Management 48(1): 300-305.

http://dx.doi.org/10.1016/j.enconman.2006.04.011

Pajchrowski, G.; Noskowiak, A.; Lewandowska, A.; Strykowski, W. 2014. Materials composition or energy characteristic - what is more important in environmental life cycle of buildings, Building and Environment 72: 15-27. http://dx.doi.org/10.1016/j.buildenv.2013.10.012

Parasonis, J.; Keizikas, A.; Kalibatienè, D. 2012. The relationship between the shape of a building and its energy performance, Architectural Engineering and Design Management 8(4): 246-256. http://dx.doi.org/10.1080/17452007.2012.675139

Porto, S. M. C.; Cascone, G. 2013. A building characterizationbased method for the advancement of knowledge on external architectural features of traditional rural buildings, Informes de la Construcción 65(532): 481-496. http://dx.doi.org/10.3989/ic.12.086

Russo, P.; Riguccio, L.; Carullo, L.; Tomaselli, G. 2013. Using the Analytic Hierarchical Process to define choices for reusing rural buildings: application to an abandoned village in Sicily, Natural Resources 4: 323-332. http://dx.doi.org/10.4236/nr.2013.44039

Saaty, T. L. 1980. The analytic hierarchy process: planning, priority setting, resource allocation. New York: McGrawHill. 287 p.

Eglè ŠIOŽINYTĖ. PhD student at the Department of Architectural Engineering formerly, and at the Department of Construction Technology and Management at present, Vilnius Gediminas Technical University, Lithuania. Research interests: development of vernacular architecture.

Jurgita ANTUCHEVIČIENĖ. Doctor, Assoc. Professor at the Department of Construction Technology and Management, Vilnius Gediminas Technical University, Lithuania. Research interests: sustainable development, construction business management and investment, multiple criteria analysis, decision-making theories and decision support systems.

Vladislavas KUTUT. Doctor, Assoc. Professor at the Department of Construction Technology and Management, Vilnius Gediminas Technical University, Lithuania. Research interests: implementation of technological processes and restoration of heritage objects.
Staniūnas, M.; Medineckienė, M.; Zavadskas, E. K.; Kalibatas, D. 2013. To modernize or not: ecological-economical assessment of multi-dwelling houses modernization, $\mathrm{Ar}$ chives of Civil and Mechanical Engineering 13(1): 88-98. http://dx.doi.org/10.1016/j.acme.2012.11.003

STR 2.02.01:2004. Technical Construction Regulation "Residential Buildings". Republic of Lithuania, 2004 (in Lithuanian).

STR 2.05.01:2005. Technical Construction Regulation "Thermal Technologies of Partitions of a Building". Republic of Lithuania, 2005 (in Lithuanian).

Šešelgis, K.; Baršauskas, J.; Čerbulènas, K.; Kleinas, M. 1965. Vernacular architecture of Lithuania: rural places and buildings. Vol. 1. Kaunas. 151 p. (in Lithuanian).

Šiožinytè, E.; Antuchevičienè, J. 2013. Solving the problems of daylighting and tradition continuity in a reconstructed vernacular building, Journal of Civil Engineering and Management 19(6): 873-882. http://dx.doi.org/10.3846/13923730.2013.851113

Yüksek, I.; Esin, T. 2013. Analysis of traditional rural houses in Turkey in terms of energy efficiency, International Journal of Sustainable Energy 32(6): 643-658. http://dx.doi.org/10.1080/14786451.2013.769989

Volvačiovas, R.; Turskis, Z.; Ignatavičius, Č.; Ustinovičius, L.; Ruzgys, A. 2013a. Considering the issue of renovating public buildings with reference to in-kind investigations into wall heat transfer coefficients, Engineering Structures and Technologies 5(2): 82-91. http://dx.doi.org/10.3846/2029882X.2013.811783

Volvačiovas, R.; Turskis, Z.; Aviža, D.; Mikštienė, R. 2013b. Multi-attribute selection of public building retrofits strategy, Procedia Engineering 57: 1236-1241. http://dx.doi.org/10.1016/j.proeng.2013.04.156

Wang, W.-C.; Yu, W.; Yang, I.-T.; Lin, C.-C.; Lee, M.-T.; Cheng, Y.-Y. 2013. Applying the AHP to support the best-value contractor selection - lessons learned from two case studies in Taiwan, Journal of Civil Engineering and Management 19(1): 24-36.

Zavadskas, E. K.; Antucheviciene, J. 2007. Multiple criteria evaluation of rural building's regeneration alternatives, Building and Environment 42(1): 436-451.

Zavadskas, E. K.; Vilutiene, T.; Turskis, Z.; Tamosaitiene, J. 2010. Contractor selection for construction works by applying SAW-G and TOPSIS Grey techniques, Journal of Business Economics and Management 11(1): 34-55. http://dx.doi.org/10.3846/jbem.2010.03

Zavadskas, E. K.; Turskis, Z. 2011. Multiple criteria decision making (MCDM) methods in economics: an overview, 17(2): $397-427$. http://dx.doi.org/10.3846/20294913.2011.593291 http://dx.doi.org/10.3846/13923730.2012.734851 